\title{
AN ASSESSMENT ON THE IMPORTANCE OF HUMAN CAPITAL IN ECONOMIC GROWTH
}

\author{
Ugur Filiz ${ }^{1}$
}

DOI: https://doi.org/10.31410/ERAZ.2019.53

\begin{abstract}
Even though the emergence of the human capital theory was shaped in the context of microeconomics, it was applied to macroeconomics eventually by the implementation of the microeconomic production function at the national or economy-wide level. There are several economic growth models introduced in the literature on this matter over the years by placing aggregate production function in the center of their models, which lay the foundation of studies focusing on economic development. However, development of 'new growth theory' particularly draw attention to the relationship between human capital and growth that is followed by the efforts aiming to bring an explanation to the differences of growth across countries by considering several possible variables of growth.
\end{abstract}

New growth theory attempted to bring an explanation to the process of economic growth in the long term through endogenous forces such as human capital, knowledge and information technology which also constituted the foundation of today's modern economies. Economic growth has been linked to an increase in knowledge, quality, and diversity of human capital rather than just a cumulative increase in the labor force. Consequently, human capital has been recognized as one of the significant factors in the process of economic growth in the literature, considering its positive contribution to creating more output in growth. However, it is noteworthy to state that literature on this topic seems to constitute some weaknesses methodologically and conceptually as well as empirical researches due to revealing reverse results.

In this context, this paper aims to conduct a literature review to develop an understanding of the human capital concept and its importance in economic growth. Accordingly, the concepts of human capital and economic growth are analyzed theoretically by showing findings of some research in the literature on the relationship between both variables which indicated that human capital could have a significant positive impact on economic growth. As of theoretical character of the study, the paper is based on the systematic review of the literature on theories of economic growth by making use of secondary data like journals, papers, websites and various magazines as the primary sources to bring an explanation to the correlation between both variables.

Keywords: Human capital, economic growth, human resources.

\section{INTRODUCTION}

$\mathrm{H}^{2}$ uman capital is a term which plays an essential role in both microeconomics and macroeconomics. With the start of the new millennium, education and human capital have strengthened its important position more and more by representing the key elements of modern economies. In this context, skill-intensive industries have been the main focus area of developed countries to be able to maintain their leadership in the world economy. Therefore, transforming to an information society has been the primary goal of the modern societies in which information and knowledge are critical inputs and outputs of almost all economic processes.

As a consequent, the interest in researches on the impacts of human capital on economic growth has increased, and it led to extensive analyzes by economists and policymakers in the last few

Szent Istvan University, Gödöllö, Páter Károly u. 1, 2100, Hungary 
decades. The first conceptual framework which describes the relationship between human capital and economic growth dates back to pioneer empiric work of Mincer [1], Schultz [2] and Becker [3], who challenged the traditional approach to human capital recognizing human capital as physical capital. This change made it possible to consider making investments in human capital through education, training, and health. It is presumed that investments in these areas will increase the output and economic growth in return. For this reason, human capital started to be recognized as one of the key elements of economic growth. Moreover, it also specified that human capital, as a vital instrument to control or influence related factors, can have an impact economic growth [4].

\section{THEORETICAL FRAMEWORK}

\subsection{The concept of human capital}

Origins of the concept of human capital dates back to macroeconomic development theory. In the 1950s, the main production factors were land, labor, physical capital, and management [1] [5]. However, in the 1960s, economists had a struggle in bringing an explanation to the growth of the US economy by using the main production factors of the period [2]. The perception of physical capital as the most crucial factor of economic success was defined by empiric work of Becker [5], Schultz [2], and Mincer [6]. The underlying presumption of the human capital theory was to take people's learning capability as a comparable value with other resources of good and services production process [7].

"Human Capital" term in modern economics literature was used by Schultz first time. Spending for human capital has been defined as an investment rather than consumption by Schultz [2]. Also, the first conceptual framework, which estimates the value of assets as part of human capital, was introduced by Weisbrod [8] in the same year by integrating capital values of people into an analytical function.

The human capital theory is applied to economics first time by members of the Chicago school, Becker and Mincer. Becker's [5] model of individual investment brought an original approach to human capital theory in which human capital was taken as something similar to 'physical means of production.' Definition of making an investment in human capital according to Becker [5] is "all activities that influence future real income through the embedding of resources in people". According to Weisbrod [9], spending on education, training, information, health, and labor mobility can be counted as human capital investments.

Human capital is a complex theoretical concept which is not defined clearly while in general it refers to the people as resources and their skills that have a positive effect on their productivity [10]. According to a broad definition made by OECD [11], human capital means 'the knowledge, skills, competencies and other attributes embodied in individuals that are relevant to economic activity.". Lynch [12] suggests that there are three ways of developing human capital, such as formal schooling, on-the-job training, and off-the-job training. In the future, it is expected to regain benefits of all these investments on the individuals. The critical factor of Becker's model [5] is that the main purpose of investment on education is the expectation of having higher rates of earnings in the long term by preceding time and possible gains in the of investment.

A central assumption of the human capital theory is that as a result of their investments in training and education, individuals with higher human capital will be more productive by increasing 
their abilities which will also give them the opportunity of having higher earnings compared to unskilled individuals. According to remarks of Becker [5], schooling helps individuals to increase their earnings and productivity by developing their skills and knowledge, which lead to developing a better understanding of analyzing problems. The human capital concept also states that the collection of physical capital has no value without any individuals who have required capabilities to utilize the money and equipment. Legge [13] emphasizes that the success of any organization relies on the quality of the employees since the quality of output is determined by the quality of input.

\subsection{The concept of economic growth}

In order to understand the definition of economic growth, it is necessary to define economic development as well. Economic development refers to a process of a cumulative and sustainable increase in the real national product of a national economy as a result of economic, social, quantitative, and qualitative changes. On the contrary, economic growth is related to a more limited concept [14]. In most of the time, the term 'growth' is associated with a quantitative increase. The most precise explanations of the growth in this context can be found, particularly in Kuznets' writings. Kuznets [15] describes economic growth as a mainly quantitative concept, and he also emphasizes that significant progress in the theoretical analysis of growth can only be possible by putting consideration of the quantitative aspect in the center [16].

Thus, economic growth refers to a process of a quantitative increase in national income per capital centered around functional relations between the endogenous variables. It means that the definition of growth has a limitation of being bound to a particular measurement. For instance, an increase in some statistical indicators of an economy such as GDP, GNP, production capacity, are associated terms which are involved in the boundaries of economic growth concept. Therefore, in other words, while economic development gives an idea about the increase in the standard of life as a result of growth in an economy, economic growth is more about a conceptual approach regarding macro-economic indications, an increase of national economies and especially GDP per capita. Economic growth is a complex and long-term occurrence which brings along some limitations as extravagant population rise, limited resources, inadequate infrastructure, ineffective utilization of resources, unnecessary government interventions, institutional and cultural forms. In the concept of economic growth, it is assumed that the reason for changes in potential output is the changes in factors of labor and capital or increase in productivity of factors [17].

Making a mention of both similarities and differences between economic growth and economic development would help to understand economic growth concept better. Firstly, speaking of differences, economic development represents a broader perception by including qualitative changes of economy and society while economic growth approaches from quantitative aspect to economic activities. In the literature, the term of development represents a higher macro-economic level. Therefore, the term of growth is mostly used in literature for developed countries, whereas researchers refer to the term of development regarding developing countries in general. However, there are also some common similarities between economic growth and development. Firstly, they both have a stimulating impact on the economy as well as they are both constant processes. Secondly, in order to increase efficiency, allocation, and utilization of resources are both considered part of the growth and development processes. Last but not least, growth and development can create a positive impact on the standard and quality of life by contributing to their progress [14]. 


\section{HUMAN CAPITAL AND ECONOMIC GROWTH MODELS}

Even though the concept of human capital was initially developed in a microeconomic context, finally, it has been applied to macroeconomics as well. This relation between human capital and macroeconomics has emerged as a result of Lucas's [18] contributions particularly. In the past few decades, human capital has been the main focal point of different researches towards explaining possible sources of economic growth. In the new millennium, human capital is a prominent determinant in the economic grow th of modern economies. Investments in schooling have started to be considered as a critical element of development strategies. Over the years, it is understood that it is quality of human capital, which is determined by knowledge and skills of individuals determines, that modern economies depend on in order to provide sustainable growth by increasing productivity with the help of technology as well [19].

In the growth literature of the 1950s and 1960s, the long-run growth rate had an exogenous character to the model. In the $1980 \mathrm{~s}$, it is clearly understood that neoclassical exogenous growth models were theoretically unsatisfactory in explaining long-growth since technological changes were not included in the model. Romer [20] tried to 'endogenize' sources of the growth by challenging the dominant concept of the period so that the growth model rate could be incorporated into the model. In this context, two different approaches emerged regarding the determination of human capital within economic growth models [33].

Importance of human capital in the economic growth process is emphasized by endogenous growth theories which are introduced to the literature by Lucas [18] and Romer [20]. They provided the main insights of today that economies can grow if they can manage to develop skills and knowledge of human capital sustainably. In other words, the reason underlies behind economic growth was not only an exponential increase in the labor force but also improvements in labor quality. Another contribution to human capital's position at present belongs to North and Thomas [21] who defined growth simply as having more educated people. An increasing labor force can be a positive factor only if workers have motivation and commitment in order to be more productive as well. Therefore, sustainable growth of an economy relies on the compensation of education, training, and productive employment. Acemoglu and his colleagues [22] also draws attention to the issue of incentives to encourage people to educate themselves and develop their knowledge.

Exogenous standard neoclassical growth model developed by Solow [30] refers to an aggregate production function as $\mathrm{Yt}=\mathrm{F}(\mathrm{Kt}, \mathrm{Lt}$. At). In this function, $\mathrm{Y}$ refers to output, $\mathrm{K}$ refers to capital, L refers to labor, and A refers to the index of technology or efficiency. The primary assumption of Solow is that F has a neoclassical character since it is described by "constant returns to scale, decreasing returns to each input, and a positive and constant elasticity of substitution". In this equation, it is accepted that a constant rate of saving and amortization is related to the evolution of the capital stock. The growing rate of labor and technology is exogenous exponential. Growth would sustain if there would only be ongoing technological progress in this model [31].

Another simple way of introduction of human capital was suggested by Romer, Mankiw, and Weil [4]. They brought a simple extension to the Solow model, which is described as a hu-

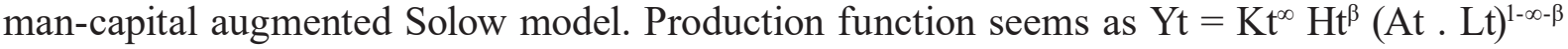
[32] where Y refers to output, A refers to technology, K refers to physical capital, H refers to human capital and L refers to labor. In this extension version, human capital goes into reverse 
standard Cobb-Douglas production function as a separate input with Harrod-neutral technological progress. The elasticity of output to related inputs are measured by the exponents $\infty, \beta$ and $1-\infty-\beta$. The main assumption is that the economy is in a steady state and the function shows constant returns to scale but diminishing returns to reproducible factors. Moreover, as similar to the Solow model, the growing of the population, and the level of technology demonstrates exogenous rates [31].

In the first approach, which is formulated by Lucas regarding the accumulation of human capital as the engine of the growth, entry of human capital into production function was quite similar to the entry of technology to the production function in Solow model. In this model, technological improvements were embedded in capital accumulation. It is assumed that two representative agents in the economy can control two variables First variable was a level of consumption which was used to determine the accumulation of physical capital while the second variable wads allocation of time between work and skill gaining which affects future productivity of an agent [18]. In this model, production function is $\mathrm{Yt}=\mathrm{AKt} t^{\beta}(\mathrm{ut} \mathrm{h} 8 \mathrm{Lt})^{1-\beta}$ ha, $\mathrm{t}^{\gamma}$ where $\mathrm{Y}, \mathrm{A}, \mathrm{K}$ and $\mathrm{L}$ refers to output, technology, capital and labor whereas $\mathrm{h}$ refers to fraction of an individual's time distributed to work, h refers to human capital of the representative agent and ha refers to average human capital in the economy. Main assumptions of the model are the level of technology is taken constant, population growth is accepted exogenous, and most importantly, recognition of human capital evolving [18].

In the second approach of the endogenous economic growth model, the primary assumption of the Solow model is still sustained, which means technological progress is taken as a key element of economic growth here as well. However, technological changes are not left unmodeled anymore by identifying technological improvements as results of intentional research and development activities in response to economic incentives. The difference in this approach gives human capital a different role by changing the entry of human capital. The entry of human capital into these models no longer become as an independent source of sustained growth, but it catalyzes technological advancement [31].

In this context, Nelson and Phelps [34] emphasized the importance of individual's level of human capital in terms of adaption to technological changes and introduction of new technologies. In other words, accumulation of human capital is recognized as an accelerating factor for the spread of technological changes and advancements. The weakness of the model of Nelson and Phelps was human capital's role was seen as just an accelerator to close the gap between advanced leaders of technology. Romer [20] developed this concept by carrying it from just the adoption of technologies to the new technology creation stage through research and development activities. However, it is necessary to have highly skilled labor, which is seen as single but the most critical input of the model. In both Romer's and Nelson and Phelps's approaches, stock of human capital is seen primary determinant of the technological advancement [27].

Romer, in his model, tried to bring an explanation to the sustainable growth of advanced countries. He endogenized technological progress by introducing a research and development sector in order to present how advanced countries could manage to maintain sustained growth. The aggregate production function in the Romer model is $\mathrm{Y}=\mathrm{K}^{\infty}(\mathrm{ALy})^{1-\infty}$ while capital accumulation is $\mathrm{K}=\mathrm{skY}-\mathrm{dK}$ and population growth is $L / \mathrm{L}=\mathrm{n}$. [35]. There are three sectors in the economy of Romer's model as a final-goods sector, an intermediate-goods sector, and a research sector. Designs, in order to produce new capital goods, are done by the research and develop- 
ment sector by using human capital and present accumulation of knowledge, and then they are sold to the intermediate-goods sector. The production of intermediate capitals good is completed by using designs and savings of the economy which is followed by incorporation of labor and human capital in the final-goods sector in order to produce the final output [27].

\section{IMPACT OF HUMAN CAPITAL ON ECONOMIC GROWTH}

According to the literature review, there are two ways for human capital to contribute to economic growth. Firstly, human capital can be taken as an independent factor which directly takes part in the production process and helps to create more output. In this case, we can talk about the direct contribution of human capital to economic growth by generating some output, which is described as 'level effect'. Other way draws attention to the contribution of human capital in technology through education since it can help to innovation, adoption, and diffusion of new technologies. In this way, human capital contributes to productivity growth, which is described as 'rate effect' [23].

Several types of research can be found in the literature regarding the contribution of human capital in the growth process for both developing and developed countries. First of all, Barro [24] revealed a positive effect of enrolment rates to primary and secondary school in economic growth. In the research carried out by Barro and Sala-i-Martin [25], a strong positive correlation was found out between average schooling years and economic output since average schooling years created significantly positive results on the economic output. Jorgenson et al. [26] tried to investigate sources of economic growth in the United States from 1977 to 2000 by using input-output analysis method, and they found out that investments in information and higher education were the primary determinant of economic growth.

In another research conducted by Bloom et al. [36] concerning human capital and economic growth relationship, results showed that schooling and life expectancy were two factors which contributed positively to economic growth while improving health standards at the same time. Increasing the output due to the opportunity of higher capital accumulation and higher labor productivity was another result revealed by findings of the research. Musibau and Rasak [28] researched Nigeria by applying two channels to his study to investigate the importance of human capital for economic growth through the impact of education. At first, human capital is taken as an independent factor of the production process, and the contribution of human capital on economic growth has been examined through technology. Both test channels proved that a well-educated labor force provides a significantly positive contribution to economic growth.

More recently, Zhang and Zhuang [29] investigated the effect of the human capital's composition on economic growth in the economy of China. It is reported that higher education's role in economic growth was more important than primary and secondary education. Also, the level of development and economic growth in regional level is associated with the composition of human capital. Findings of the research also showed that the outcome of higher education is more beneficial in developed countries is higher, whereas developing countries are more dependent on primary and secondary education. 


\section{CONCLUSION}

Although it is possible to encounter plenty of evidence regarding human capital at the microeconomic level, it seems like there is some difficulty in finding the same wide range of research at the macroeconomic level. However, over the years, the number of researches regarding the contribution of human capital in economic growth has increased significantly for both developing and developed countries since.

As can be seen in the literature review, human capital has managed to take place in both neoclassical and endogenous growth models, and a significant role has been given to human capital concept by theoretical and empirical analyses of economic growth. Despite there is a general agreement regarding the description of human capital, there is a struggle in the process of human capital measurement. Different elements and indicators have been used by economists in order to measure human capital. Formal schooling has been one of the most common indicators that have been used in the literature as a result of Barro's efforts. This concept made it possible to bring explanations to the rapid development of developing countries, especially as well as constituting a guide to developed countries to maintain their leadership in the world economy.

Despite the difficulties and limitations on the topic, several types of research conducted in the literature showed a positive correlation between human capital and economic growth. In modern economies, for both developing and developed countries, exponential and qualitative increase in human capital is seen as a critical factor for their development through its significant positive impact on economic growth. In other words, it can be concluded that there is a strong relationship between human capital and economic growth, considering that efficient and wise utilization of knowledge and skills of people can boost the economic growth significantly. Therefore, developing a better understanding of the relation of modern economies to the quality of human capital is necessary to sustain long-term economic growth. In this context, investments in education should be taken into account carefully in development strategies as skill sets and motivation of people would be a determinant factor in the development of the economy and sustaining a healthy economic growth rate.

Finally, it is also important to point out that there are still several studies being conducted in order to improve quality of data regarding the impact of human capital in economic growth which also includes research revealing different results and reporting possible adverse effects of human capital on economic growth. Therefore, it is necessary to follow up-to-date researches closely in order to overcome methodological and conceptual issues regarding the human capital concept at the macroeconomic level.

\section{REFERENCES}

[1] Mincer, J. (1962). Labor Force Participation of Married Women: A Study of Labor Supply, Princeton University Press, pp. 63-105.

[2] Schultz, T. W. (1961). Investment in Human Capital, The American Economic Review, 51, pp. 1-17.

[3] Becker, G.S. (1962). Investment in Human Capital: A Theoretical Analysis. Journal of Political Economy, 70(Supplement), pp. 9-49.

[4] Mankiw, N.G., Romer, D., \& Weil, D.N. (1992). A Contribution to the Empirics of Economic Growth. Quarterly Journal of Economics, 107, pp. 407-437. 
[5] Becker, G.S. (1964). Human Capital: A Theoretical and Empirical Analysis with Special Reference to Education, University of Chicago Press.

[6] Mincer, J. (1974). Schooling, Experience and Earnings, Columbia University Press.

[7] Lucas, R. (1990). Why Does not Capital Flow from Rich to Poor Countries, American Economic Review, Volume 80, No 1, pp. 6-92.

[8] Weisbrod, Burton A. (1961). The Valuation of Human Capital, The Journal of Political Economy, Volume 69, pp. 425-436.

[9] Weisbrod, Burton. A. (1966). Investing in Human Capital, The Journal of Human Resources, Volume 1, pp. 5-21.

[10] Becker, G.S. (1975). Human Capital, 2nd Edition, University of Chicago Press.

[11] OECD (1998). OECD Insights: Human Capital, The Value of People, pp. 29.

[12] Lynch, L. M. (1991), The role of off-the-job versus on-the-job training for the mobility of women workers, American Economic Review, Papers and Proceedings, Vol. 81, pp. 151-6.

[13] Legge, K. (2005), Human Resources Management: Rhetoric and Realities, Palgrave, Macmillian, 2005.

[14] Haller, Alina-Petronela (2012). Concepts of Economic Growth and Development Challenges of Crisis and Knowledge, Economic Transdisciplinary Cognition, Vol.15, Issue 1, pp. 66-71.

[15] Kuznets, S. (1955). Toward a Theory of Economic Growth, National Policy for Economic Welfare at Home and Abroad, pp. 16.

[16] Kuznets, S. (1949). Suggestions for an Inquiry into the Economic Growth of Nations, Problems in the Study of Economic Growth, pp. 6.

[17] Arthur, A. J. (1964). The Meaning and Measurement of Economic Growth, Supplement to the Treasury Information Bulletin, Commonwealth of Australia, November.

[18] Lucas, R.E. (1988), On the Mechanics of Economic Development, Journal of Monetary Economics, Vol. 22, 1, pp. 3-42.

[19] Temple, Jonathan (1999). The New Growth Evidence, Journal of Economic Literature, Vol. 37, 1, pp. 112-156.

[20] Romer, Paul, 1986. Increasing Returns and Long-run Growth, Journal of Political Economy, 94(5), pp. 1002-1037.

[21] North, D., and Thomas R.P., 1973. The Rise of the Western World: A New Economic History, Cambridge: Cambridge University Press.

[22] Acemoglu, D., Johnson S., and Robinson J.A., (2005). Institutions as a Fundamental Cause of Long-term Growth in Handbook of Economic Growth, Philippe Aghion and S. Durlouf, Eds., Volume 1A, Chapter 6, pp. 386-414.

[23] Freire-Seren, M. J. (2001). Human Capital Accumulation and Economic Growth, Investigaciones Economics, 3, pp. 585-602.

[24] Barro, R. J. (1991). Economic Growth in a Cross Section of Countries. Quarterly Journal of Economics, 106(425), pp. 407-43.

[25] Barro, R., \& Sala-i-Martin, X. (1995). Economic Growth. McGraw-Hill, New York, pp. 54-55.

[26] Dale W. Jorgenson, Mun S. Ho, and Kevin J. Stiroh. 2003. Lessons from the U.S. Growth Resurgence, Journal of Policy Modeling, 25, 5, pp. 453-470.

[27] Romer, Paul M. (1990). Endogenous Technological Change, Journal of Political Economy, Vol. 98, 5, pp. S71-S102.

[28] Musibau, B. A., \& Rasak, A. A. (2005). Long Run Relationship Between Education and Economic Growth in Nigeria: Evidence from Johansen's Cointegration Approach. Cornel University, Dakar - Senegal. 
[29] Zhang, C., and Zhuang, L. (2011). The Composition of Human Capital and Economic Growth: Evidence from China Using Dynamic Panel Data Analysis, Volume 22, Issue 1, pp. 165-171.

[30] Solow, Robert M. (1956). A Contribution to the Theory of Economic Growth, Quarterly Journal of Economics, Vol. 70, 1, pp. 69-94.

[31] Schütt, F. (2003). The Importance of Human Capital for Economic Growth, Band 27, Bremen University, International Management Institute, pp. 9.

[32] Javier, A., Domenech, R. and Molinas C. (1996)/ Macroeconomic Performance and Convergence in OECD Countries, European Economic Review, 40, pp. 1683-1704.

[33] Aghion, P. and Howitt, P. (1998). Endogenous growth theory, Cambridge, MA: MIT Press, pp. 327.

[34] Nelson, Richard R. Phelps, and Edmund S. (1966). Investment in Humans, Technological Diffusion, and Economic Growth, American Economic Association Papers and Proceedings, Vol. 56, 1-2, pp. 69-75.

[35] Rossi, L. (2011). Lectures of Endogenous Growth Models, Goethe University.

[36] Bloom, D. E., Canning, D., \& Sevilla, J. (2004). The Effects of Health on Economic Growth: A Production Function Approach. World Development, pp. 1-13. 